\title{
LIFE ON THE STREETS OF DURBAN: NO MILLIONAIRE ENDING
}

\section{Vishanthie Sewpaul, Ingrid Osthus, Christopher Mhone, Emma Sibilo, Sithembile Mbhele}

\section{INTRODUCTION}

This article is based on two years of engagement with children and youths living on the streets of Durban. Our work was informed by critical and emancipatory frameworks and combined research and social work practice. This article reports specifically on research undertaken in respect of the experiences of children and youths living on the streets in the Durban Central Business District and the survival strategies that they adopted. ${ }^{1}$ MacDonald and Terblanche (2011:85) concluded from their study in the Western Cape that: "From the researchers' point of view there was certainly no 'millionaire' ending to the story, yet from the participants' perspective street life could be likened to a millionaire's life in comparison with their home circumstances". While our research in Durban supports the researchers' view, it contests the latter assertion. Despite the extreme poverty and deprivation, often accompanied by alcoholism, violence and abuse in their family environments, the participants in our study did not believe that life on the streets was actually better than life at their homes. The words of one of the youths captured this most poignantly: "Ma'am, sometimes we talk about it in the shelter and we compare - home, shelter, street and we don't know which one is worse."

While there might be the assumption that the street must be better than home for the children to have left home in the first instance, our empirical data do not support this. Before the presentation of the key findings, we discuss the prevalence of the phenomenon, the complexities of definition, the factors that contribute to children migrating to the streets, and we briefly outline the research methodology.

\section{PREVALENCE OF THE PHENOMENON}

The mobility of street children makes it difficult to ascertain precise statistics. There has been a steady rise in the population of children living on the streets in recent years. Various researchers in the 1980s and early 1990s estimated that it was anything between 6276 and 9 390, with ages ranging between 7 and 16 years (Tudoric-Ghemo, 2005:11). In the early 2000s it was estimated that there were 15000 street children (Kruger \& Richter, 2003), thus reflecting an increase of almost $60 \%$ within a relatively short period.

Ward, Seagar and Tamasane (2007) argue that counting the homeless accurately, whether adults or children, is an extremely difficult task because of the high mobility of this population. During our work and research we found that the children who are on the streets during the day are a fraction of the total population - a number of them are either in police cells, police vans or doing daytime piece-work. It is estimated that there are about 3000 children and youths living on the streets of Durban (Trent \& Von Kotze, 2009). Whatever the statistics, children and youths living on the streets constitute an extremely vulnerable and marginalised group, which warrants research and action by social workers and related occupations and professions. Our

\footnotetext{
${ }^{1}$ This study was made possible through funding from the National Lotteries Board. We are also indebted to the South African Netherlands Partnership for Alternatives in Research and Development (SANPAD) that funded an earlier phase. The policy and practice implications of the early research served as precursors to this current research and work with children and youths living on the streets of Durban.
} 
practice experience in the field, which alerted us to the complexities of definition, prompted this empirical study into the experiences and survival strategies of children and youths living on the streets.

\section{THE COMPLEXITIES OF DEFINITION}

We do not subscribe to the conventional distinction between children on and off the streets (Sewpaul \& Osthus, 2009) for both pragmatic and ethical reasons, and we acknowledge the complexities and the power of context in defining "street children" and "street youth" (though we do not support the use of these labelling concepts, preferring instead "children and youths living on the streets"). Cox and Pawar (2006:326) provide a definition that is broad enough to include the wide variety of children and lifestyles that prevail on the street: "Street children are those who spend most of their time on the streets whether working or not; have tenuous ties, or no ties at all, with their families; and have developed specific survival strategies." Perhaps accepting a functional rather than legal approach to age (just as we do in this article), Cox and Pawar (2006) do not include age as a criterion in their definition.

For the purpose of this study we accept the argument posited by Epstein (1996:290) who discusses homelessness generally and asserts that in spite of the diversity involved, homelessness and street life share the following four characteristics: (1) a public disclosure of personal destitution; (2) the abandonment of a futurist orientation; (3) ceding one's entitlement to private and personal space; and (4) the sense of permanence with respect to personal and social relations is thrown into question because one's ability to gain protection is challenged. All these characteristics are evident in this study.

\section{RESEARCH METHODOLOGY}

The research adopted a triangulated approach, incorporating the qualitative and quantitative paradigms. Triangulation is important in social research; as Humphries (2008:98) indicates, "it offers a range of perspectives on what the reality or the 'truth' of a situation is". Within the qualitative paradigm, triangulation included several data-collection strategies: in-depth case studies and interviews; home visits, where feasible; multiple focus group meetings; and observations by working with the children and youths in their own life spaces on the streets. The qualitative research was guided primarily by availability sampling, with the key criterion being participants' willingness to engage with us. The over-riding principles that we were guided by were: doing no harm; that our interactions were beneficial for the participants; that the children and youths were involved in all major decision-making with regard both to the research and the practice aspects of our work; participant inclusion in major events like workshops and conferences (Sewpaul, Osthus \& Mhone, 2011); and anonymity in the reporting of the data. No identifying details of the participants are provided and pseudonyms are used in this article. The quantitative research involved a social survey with 100 participants. As there were some spoilt questionnaires, the final number included in the survey was 89 . We engaged the core group of young people whom we worked with and who were involved in the qualitative study to help us draw up the questionnaire, which was translated into isiZulu. This core group facilitated our entry into the broader population of children and youths living on the streets and they helped us to complete the questionnaires. The participants also made decisions about what they wanted to do with the results of the study, and engaged in advocacy initiatives in accordance with the critical and emancipatory approaches that guided the research. It is not within the scope of this paper to report on this. 
Multiple focus groups on a weekly basis were conducted over a period of six months. Participants ranged from five to ten males and two to five females per focus group, reflective of the wider street children and youth population, where males predominate. Understanding the factors that contribute to children migrating to the streets forms an important backdrop to an empathic appreciation of their life on the streets, as in some respects these form a seamless whole, with the characteristics of home life often merging into those of street life.

\section{LITERATURE REVIEW: FACTORS CONTRIBUTING TO CHILDREN AND YOUTH LIVING ON THE STREETS}

Children and youths migrate to the streets for various reasons. The literature suggests that there are many interrelated push and pull factors that play a role in the path to the streets (Ward et al., 2007). Karabanow (2003) indicates that, although the street child population is by no means homogenous, the children do share some common characteristics and experiences, a view supported by Epstein (1996). Before the 1980s the literature on aetiology focused mainly on individual factors, such as needing independence, not wanting to abide by rules, depressive and/or antisocial character, "personality pathology", searching for fun and excitement, and involvement in drugs, alcohol and sexual deviance (Karabanow, 2003). More recently the lack, or the poor implementation, of policies to strengthen communities and families has been seen as contributing to the migration of children to the streets. Poverty, combined with factors such as lack of literacy, abuse and HIV/AIDS, is cited by many as being the main driving force behind the increasing numbers of children migrating to the streets (Chetty, 1995; Lalor, 1999; Motala \& Smith, 2003; Swart-Kruger \& Richter, 1997; Veale \& Doná, 2003). Evans (2002) indicates that poverty severely constrains families' ability to provide for their children and places great pressure on adult-child relationships. Based on her research findings in Tanzania, Evans (2002) concluded that abject poverty affected the majority of the participants' households; $75 \%$ of the young people interviewed cited the family's inability to meet their basic needs as a major factor that forced them to leave the home. MacDonald and Terblanche (2011) found material, emotional and social deprivation, problems at school and peer influence to be key factors contributing to the phenomenon of street life among children in the Western Cape.

It is important to appreciate the social impact of HIV/AIDS, which has left a number of children orphaned. In Southern Africa many households are experiencing extreme stress, as this is the region that is hardest hit by the HIV/AIDS pandemic. Long-term sickness and high death rates impose enormous costs and burdens on households, including care of the sick, funeral expenses and emotional trauma, and reduce the capacity to undertake work. Assets and savings are often used to counteract the loss of income, as saving life is regarded as more important than saving assets. Deaths, particularly among adults, can further reduce the income to a household, as well as leaving productive work undone, including the care of children. This is exacerbated in the case of AIDS deaths, as an adult's death is often swiftly followed by the death of his/her spouse (Ansell \& Van Blerk, 2004).

In South Africa the impact of neoliberal economic policies on family life cannot be overlooked (Sewpaul, 2005). Policies such as Growth Employment and Redistribution and the Accelerated Shared Growth Initiative for South Africa have contributed to a society that is divided into a few ultra-rich and a majority of poor people. As the policies are conducive primarily to capital accumulation and not to people's development, people's welfare is relegated to the market, leaving families and children in situations of deprivation. In neoliberal capitalistic societies "what emerge are gigantic monopolies, which cripple creativity, freedom and participation in 
economic, political and social efforts. The end result is the existence of a massive global population of silenced, blind and apathetic consumers, on the one hand, and a disadvantaged, desperate and starving population, on the other. Neoliberalism has made it possible for a 'powerful few' to tie up global resources in terms of ownership, production and massive capital gains" (Okosun, 2008:4).

\section{RESEARCH RESULTS}

In this article we report on the experiences of children and youths living on the streets and the survival strategies that they adopt. This discussion is preceded by a presentation on the age and gender characteristics of the participants.

\section{AGE}

In the focus group it was indicated that some of the males came onto the streets at nine years of age; for the girls the minimum age recorded when they first came to the streets was 13 . In the social survey about a quarter of the youths reported ages between 14 and 17 years, and about one third reported belonging to the 18- to 21-year-old group. A small minority reported belonging to the 10- to 13-year-old age group, and to the over-21 year group. While the legal definition of children includes those up to 18 years of age, we found that the ages of those on the streets tend to be quite arbitrary. Many children and youths living on the streets do not possess identity documents (IDs). The social survey that we conducted reflected that $75.2 \%$ of the participants did not have IDs, which constitutes a denial of their right to citizenship. It also denies one of their socio-economic rights, as one cannot secure a job without an ID, nor can one apply for any state benefits even if one qualifies for them. The majority of this $75 \%$ did not have birth certificates either. We found that the youths reported varying ages depending on circumstances, e.g. it might be expedient to identify oneself as a juvenile when in trouble with the law and as an adult when seeking a job; also youths might be tempted to represent themselves as younger than they actually are in order to gain public sympathy. In addition, after 18 years of age they are often denied services for "street children". Thus, those who need and want the services might lie about their ages, which is understandable.

The National Youth Policy (based on the National Youth Commission Act No. 19 of 1996) refers to youths as those between 14 to 35 years. This inclusive approach takes into account both historical as well as contemporary conditions, where many young people lost out on their early years. Although much has changed for young people since 1994, the motivation for 35 years as the upper age limit of youth has not changed, since historical imbalances in South Africa are yet to be fully addressed. This definition is also consistent with the definition of youth in Article 4 of the African Youth Charter.

\section{GENDER}

Consistent with our qualitative findings, the social survey reflected that there are more males (71.9\%) than females $(28.1 \%)$ living on the streets. Aptekar (1991) indicated that street boys form the largest group in developing countries. This is consistent with several studies from different countries such as Zimbabwe, Angola, Zambia, Ethiopia and Sudan (Tudoric-Ghemo, 2005; Veale \& Donà, 2003). Cultural influences have a lot to do with this gender variation. Patriarchal societies attribute different roles to boys and girls in which it is more acceptable for boys to leave home at an early age than it is for girls. Furthermore, females on the street who engage in some form of domestic labour or prostitution might not be seen to be a part of a vulnerable "street children" population (Sewpaul \& Osthus, 2009). 


\section{MIGRATING TO THE STREETS}

This study revealed that children and youths migrate to the streets for one or more of the reasons mentioned above. The majority of the focus group participants mentioned poverty and unemployment, death of a parent, family conflict, alcoholism, and physical and sexual abuse, often in combination, as being the major factors. Observations during visits to homes of some of the participants substantiated these assertions. The number of service delivery protest actions and protests related to unemployment indicates that South Africa is sitting on a ticking time bomb. Vavi (2012) asserts that with 7504000 people unemployed - i.e. 36\% of the working population by the expanded definition that includes discouraged work seekers - South Africa's unemployment rate is worse than that of other comparable middle-income countries.

Migrating to the streets was not an easy process for many of the participants. The usual pattern was that they would come and stay on the streets, return home and then come back to the streets after a while. In some instances this pattern was repeated until they made a final transition to the streets with no or only intermittent contact with home. The views of some of the participants are conveyed below:

"I came here in 1999 ... I struggled a lot when I could not find food because I did not know ways of getting it ... I was 13 years old. I was eating leftovers from the Nigerians. I later decided to go back home and went back to school, but I did not stay long because I did not have shoes. When I returned I was able to look for food and I learned how to take people's chains. This became a habit and I got arrested." (young male)

"I did not have shoes", while a tangible reality, is also a powerful metaphor for the stark experience of poverty, as so cogently depicted by Diamond (2005:328) in respect of the incentive for the Rwandan genocide: "The people whose children had to walk barefoot to school killed the people who could buy shoes for theirs."

A young female, who talked about poverty, death of a parent and abuse as factors that contributed to her coming to the streets, reflected on her experience of coming to Durban for the first time:

"After our mother passed away ... we stole money and came to Durban ... At this time I am still scared of Durban for I am not used... My sister then ran away and went to some boy called Skizo ... I met a girl from Pietermaritzburg ... I told her that I want to go home and she said she wanted to go too and she had money. We then left together. When I got home I was beaten up by my grandmother ... after some time I came back here and I met these new people ... And then I got used to Durban and I stayed."

The following excerpt from a girls-only group highlights sexual abuse as a major factor contributing to girls ending up on the streets:

Gloria: "When I was 9 years old, I was raped by 13 people, and I went to social workers. And from there, I came [to the streets] when I was 12 years."

Thobeka: "Me myself, my stepfather" (quiet)

Facilitator: "Your stepfather?"

Samantha: "My stepfather also raped me. Then he died. He went to jail, and then he died after that ..." 
Nomusa: "My stepfather. Too many stepfathers are doing wrong things. If he sees you, he says ... 'This is not my child'. Then he just wants to rape you. And me too. I was staying at home. My stepfather he wanted to rape me, and then I must go to sleep outside. Then I sleep outside [on the streets]."

While there were dire circumstances that pushed them on the streets, the hope of anything better did not materialise for the majority of them, as reflected in the numerous challenges that they faced.

\section{THE CHALLENGES OF LIFE ON THE STREETS}

The children and youths on the street face numerous challenges, from lacking satisfaction of their most basic needs to experiencing extreme danger.

\section{LACK OF SHELTER AND BASIC PROTECTION: A VIOLATION OF FUNDAMENTAL RIGHTS}

Shelter is a most basic need as it protects people against harmful natural elements such as rain, wind, cold and heat and from societal threats and violations. While substance abuse is selfdestructive, many children and youth use such substances, especially glue and marijuana, as evidenced by self-reports and our observations, to mitigate the harmful effects of street life. Access to shelter and to security constitute fundamental rights that children and youths living on the streets are denied. Article 122 (b) of the South African Constitution states that everybody has the right "to security in and control over the body", and Article 261 that "Everyone has the right to have access to adequate shelter". These rights are affirmed in the Universal Declaration of Human Rights; for example, Article 3 states, "Everyone has the right to life, liberty and security of person".

Article 52 of the African Charter on the Rights and Welfare of the Child reads: States Parties to the present Charter shall ensure, to the maximum extent possible, the survival, protection and development of the child, while its preamble says: Recognizing that the child occupies a unique and privileged position in the African society and that for the full and harmonious development of his (sic) personality the child should grow up in a family environment in an atmosphere of happiness, love and understanding.

Children and youths living on the streets, reflective of some of the poorest and most marginalised and vulnerable sections of communities, epitomise the failures of societies and states to protect them, despite the duties imposed in various charters, conventions and pieces of legislation to protect the best interests of the child. One of the focus group members said:

"Life is tough on the streets - there are things that we see happening because we stay day and night on the street ... we have seen a person being stabbed to death and people stabbing girls for no reason."

This article shows that street life denies children what Article 27 of the UN Convention on the Rights of the Child (CRC) (1989) asserts as "the right of every child to a standard of living adequate for the child's physical, mental, spiritual and social development", a denial which presents enormous challenges for their survival.

\section{SURVIVAL ON THE STREETS}

The children and youths reported eking out a living by adopting various strategies: begging, street performances especially posing as stills, guarding cars, pushing trolleys at supermarkets, engaging in any available piecemeal jobs, criminal activities and engaging in transactional sex. 
The older one gets on the streets, the more likely it becomes that survival depends on piecemeal jobs and crime, as begging is often not a viable option; they are no longer small and cute enough to elicit the sympathy of the public. Seventy-two per cent of those unemployed in South Africa are between 15 and 34 years of age (Vavi, 2012). The structural barriers to employment make it extremely difficult, indeed in most circumstances impossible (especially in view of the lack of IDs), for youths living on the streets to find gainful employment. Illegal activities include theft, breaking into cars and homes, prostitution and mugging. One of the youths said:

"I sometimes climb into the flats and go through opened windows and get what I want ... looking for nice things ... If I get caught I fight with the owner."

Whatever the survival strategies, a huge blight on their lives is the constant exposure to violence from the metro police and from within their own groups.

\section{VIOLENCE INFLICTED BY THE METRO POLICE}

The participants' narratives revealed horrific experiences at the hands of the authorities who are entrusted with protecting them. They reported that the metro police often carry out raids, especially when they are sleeping, as reflected in the comments of a male youth:

"I was asleep ... I heard someone talking ... it was around three in the morning. When I went out I was blinded by the light from the torches, it was then that I realized that it was the metro police officers. All of them started beating me up, they did not say why ... They pressed me down and sprayed in my eyes some spray, as I shook them off to escape through this gap, they flung me to the razor wire and I got cut badly."

The reports of abuse and violence from the metro police were one of the common themes of the focus groups and individual interviews. We had to begin one of our focus group meetings late, as the members were nowhere to be found. When they finally arrived, they were exhausted and dirty. They said they had walked back from Stanger (74 kilometres north of Durban), which is where the metro police dumped them after beating them up. When we asked about the whereabouts of the other members, one of them said:

"Mondli has been beaten, all of us ... They were beating us with a sjambok and they threw water at us when we were in the truck. One police was about to beat Mkhancala. Imagine he cannot walk ... As I was trying to explain the beatings became more."

The experience of being rounded up by police is not unique to Durban; children in Zimbabwe report similar experiences (Sexton, 2005). The quantitative study corroborated the results of our qualitative findings. We found that $87.6 \%$ of the 89 participants reported being physically abused by the metro police; $75.3 \%$ were verbally abused, $73 \%$ reported having their belongings taken away. These included clothes, medication and identity documents. Our qualitative findings revealed that girls were often asked for sexual favours in exchange for their belongings. Over a quarter of the children and youths reported being sexually abused by the police.

During one of the workshops with service providers, organised and led by children and youths living on the streets, a female youth said:

"Some of us trying so hard to make a living but they are taken to the vans, because the police want money and if you don't have it they take you and go sleep with you. They take us and throw us in places like Stanger. We are also children. We have the rights. 
The fact that we are staying on the streets does not make us dogs, we are not rubbish, we are people. Please listen to us!"

The findings are consistent with prior research. Street children in Sudan reported that the police would catch them, beat them and take their money before releasing them, and for the girls, the police would also rape them (Kudrati, Plummer \& Yousif, 2008). Trent (2007) found that harassment by the police was identified by street children in Durban as one of their main problems. The dehumanising experiences at the hands of the authorities is a direct violation of children's rights as provided for by South Africa's Constitution, the United Nations Convention on the Rights of the Child, and regional and national policies and legislation that embrace children's rights and interests.

\section{VIOLENCE AMONGST THEMSELVES}

Street life is dangerous; it hurts and it kills! This was a message that was reiterated several times. In the focus groups participants highlighted the importance of each person taking care of him/herself. While there is a sense of friendship and common bonding, these are quite fragile and they can turn violently against each other at the slightest of provocation. One male youth said:

"We sleep with our weapons and we sleep as a group ... if we caught you searching our pockets we beat you with our shoes ... I stab because others carry 'grass slayers' so I would die if I don 't carry my knife, I first tell a person to stop harassing me."

Another youth said:

"If you are new on the streets you must be clever by stabbing someone and doing robbery."

Violence was endemic, with $47 \%$ of the males and over $60 \%$ of the females reporting witnessing violence several times a day; no girl reported witnessing violence less than once a week. Violence on the streets may be seen as a strategy of asserting control over others, with older boys asserting power over younger boys, and males over females. Violence is common within small groups and between larger groups such as the gangs of the $26 \mathrm{~s}$ and the $28 \mathrm{~s}$ [street gangs]. Parts of the city are divided into territories, and it is the gangs that determine movements and activities. When people from the different territories meet, there is risk of brutal violence. However, most violence was found to happen within the groups of friends that stay together or possibly among people from different subgroups but within the same territory.

Violence is frequently inflicted on females as a means of controlling their sexuality, keeping other boys away from them, and as a means of subjugating females to masculine dominance. The following quotation reflects the use of violence, with rape being a pervasive theme in the lives of girls.

"He caught me, he showed me a gun, he said he was gonna shoot me. ... He slept with me .... And he told me, if I go and tell the police, he's gonna catch me and shoot me. And I didn't go and tell the police. I just kept quiet." (young female)

Nomathemba said that sometimes the girls have to hide each other from their boyfriends, but this does not always end well:

"The time I was sleeping that Mandla came and was drunk. When he came there, he opened our blanket and he said to me where is my girlfriend. I told him I don't know ... and he kept asking me. After he's keep asking me, he went to others there... and 
asked where is my girlfriend, and the other one said 'hey I don't know where is your girlfriend is ...' Then Mandla took one brick and then he threw it at one of the girls."

Data reveal that females and males experience rape on the streets. Most of the males and females in the focus groups discussed being raped, the disclosures perhaps linked to the trusting relationships developed over an extended period of time. The majority in the social survey, however, denied this. Twenty-one per cent indicated that they had been raped; $69 \%$ said no and $10 \%$ chose not to answer the question. People known to the participants mostly carried out rape on the streets. Forty-four per cent of the females who had been raped indicated that the perpetrators were members of their own small group and $26.6 \%$ of the males who had been raped indicated the same. Out of the 19 that said that they had been raped, one female reported that she was raped so many times that she lost count. Another female indicated that she was raped 10 times. One male said he was raped six times. In Ethiopia $44 \%$ of females living on the street reported being raped and the average age of the first rape was 13.8 years (Lalor, 1999). While one individual at a time rapes males, females sometimes experience gang rape. Sogololo (cited in Tudoric-Ghemo, 2005:60) asserted that "male gang members often felt that they have a right to rape the girls".

Speaking on violence, sex and rape in a focus group, a male youth said:

"Haha ... someone gets killed... because it happens that you haven't had sex with the girl then some one comes and sleep with her first, the conflict begins ... Gang rape happens when a girl has many boyfriends and we come together and rape her because she is a bitch. One person starts by beating her then we come and sleep with her by force because we have been buying gifts for her, so she should pay back by having sex with all of us."

Sexual violence is an especially gendered form of violence. Females identified males from the street as the most common perpetrators of rape in the survey, with no reported difference between males from within their group of friends $(44 \%)$ or from other groups $(44 \%)$. Other perpetrators of rape reported by females included men who don't stay on the street, boyfriends and police. The females had numerous experiences of rape perpetrated by other males from the streets who did not stay with them. Some of these males were 26s [a street gang], that is, from the same territory as the girls but not living in the same group, as reported by Nomusa:

"A boy was forcing me ... He is a 26. He wanted to rape me. The first time, when ... I was 13 years old... And then I went to call the police, and then he was locked up. He was there in jail for 5 months and then he came back. Then he wanted to hit me, because me I was locking him up. ... Even other people, when they go to jail, they come back outside, then he's gonna tell the friends, 'Hey, this girl she was doing me like that ... she was telling the police' all that and then he will kill you. Another girl, she's dead here in town."

An incident with boys who belonged to the 28 s gang happened a night before one of our focus group sessions:

Thuli: "Thabo came at night time drunk with another two boys, Sibusiso and Julius; they wanted to rape us. They wanted to take me to another place and rape me. ... Sibusiso said he will catch me if I go to Workshop because I called the police for them. I was not going to sit and wait for them to rape me. ... I will not go to Workshop; I am scared to go there now that I called the police for them. Maybe he is going to stab me." 
Fear is a common means of control and in this context of sexual violence, it is a means of male control over women. Violence and dominant views of masculinity are closely linked (Gilligan, 2001; Sathiparsad, 2008). Hearn (1996:29) warns against "separating violence off from the rest of social relations between men and women" and argues that rape is a strong expression of the gendered structure of our society.

The level of violence on the streets creates uncertainty and contributes to a lack of a future orientation. Their lives are mostly focused on the here and now. While lack of a long-term vision may not be due only to high levels of violence (the high levels of HIV/AIDS plays a major role), the constant exposure to brutal violence has a huge influence on how they view their lives. Lack of control over the future, powerlessness and a sense of hopelessness often characterise their lives, as reflected by Musa:

"Since I came to the streets in 1991, I have seen a lot of my friends die and I am really afraid that next time it could be me."

The violence experienced on the streets is a mirror of the broader South African society, where violence has been normalised as a conflict-resolution strategy. South Africa is one of the most violent countries in the world. Widespread interpersonal violence and crime have affected all members of society, with schools also experiencing a high incidence of stabbing and killing (South African Institute of Race Relations, 2008).

\section{SURVIVAL SEX}

During one of the focus group discussions on the means of survival adopted by girls compared to boys, we noted that one of the girls was very uncomfortable, so we arranged for her to see one of the facilitators individually. She reported the following:

"For three days me and my friend were prostitutes, I will not lie we went to the beach and there are clubs there in Stanger Street that is where we were making money. I was like this is an easy way to get money then it became a habit."

The following quote from one of the females reflects the relationship between material need and commercial sex (see Osthus, 2011 for a fuller discussion on the relationship between commercial sex and poverty):

"Isn't it, you need money to buy food, to buy things. You need money. Sometimes you feel bad. But it's like. It gets away. You don't feel that worried. But sometimes you feel bad. But we have to do it."

In one of the focus group sessions, a male said:

"The girls are selling their bodies. They tell you that 'you do not support me and you do not buy food for me. In the morning when you go to Shoprite you come back and buy your own things' ... We have seen them sucking a penis ... They make money by selling their bodies."

In focus group discussions (Osthus, 2011) there was an admission that boys also sell their bodies. Despite their heavy condemnation of girls who sold sex, boys also did it. It was extremely taboo, and it was difficult to estimate the extent. It was rarely admitted and hardly ever talked about, but two boys, Brilliant and Sihle, shared how it happened. Brilliant explained:

"There by the road, if the boy is walking, some other car ... it comes there and he calls one boy ... And then he'll say to you that he is going to buy food for you. And then he 
will go with you, to his house, and then ... he says, 'Do that, and this, and this'. You will do it because you want money."

He said that the men who pay will ask the boy to "suck them or to eat you in the bum", and that the boy will get R50.00 for doing this. Being "eaten in the bum" was the utmost humiliation and assault to one's masculinity and it was thus selling sex to men that was taboo, not having sex for money per se.

There are many similarities to female sex work. A boy also got sex customers by walking the streets, just as they accused and condemned girls for doing. For both, the overarching motivation was money, and the need for money overruled any hesitation or aversion to doing what the customer wanted. Brilliant even recognized the similarity with female sex work as he commented on the price, "Same like a girl". Yet, there was no trace of solidarity as a consequence of the similarities. Boys did not moderate or muffle their condemnation of girls' sex work, and they did not admit their own engagement in sex work to girls. Instead of empathy with each other's extremely difficult life circumstances, the young men held on to the common-sense superior-inferior polarity between males and females (Dominelli, 2002). Despite sharing the destitution of homelessness and engaging in sex work as an incomegenerating strategy, the boys strongly asserted their superiority over the girls.

\section{CONCLUSION}

Our prolonged and intensive engagement with the children and youths, and the triangulated approaches that we adopted, gave us deep insights into the experiences and survival strategies of children and youths living on the streets. Unemployment, extreme poverty, death of a family member, family-related difficulties and abuse were the main drivers of children migrating to the streets, which was no easy process. The street might initially have represented a preferable option, but their experiences soon taught them that street life is difficult and dangerous. While they recognise the dangers, part of the difficulty is that violence is so routinised and normalised that many of them cannot comprehend a life that is any different. This is, in part, related to their sense of resignation and hopelessness, expressed by one of the youths as being "unhelpable". Another youth in a focus group meeting said: "It might be too late for us, but what can we do to prevent other children - younger children - from coming to the streets". They did not want young children to come to the streets and "suffer like us".

For those socialised into street life over many years, with little or no resources at home, it might be too late. But we tapped into their desire to make a difference and used their narratives to produce a movie on "Street Life". This movie, made with the participation of the youths who scripted and acted in it, is used to undertake preventive work in township schools. ${ }^{2}$ The message of the movie and the street youths who join us in these projects is unambiguous: Street life is dangerous; it hurts and it kills. School children view the movie and listen to the life experiences of the youths from the streets. They then discuss in small groups the major problems confronting their communities, and who and where they can go to for help. While we cannot measure the impact on whether or not the outreach actually prevents children from migrating to the streets, the responses of the children and the teachers are very positive. There is unanimous feedback from teachers and the school children that the project holds potential to 2 This phase of the work was initiated and implemented by Vishanthie Sewpaul and Ingrid Scharer
Osthus. 
help children think twice before leaving home and that it can help them to seek help and remain with their families rather than go to the streets.

We are, however, mindful of the depths of poverty of these communities, reiterated by the school children as they discussed the problems that are prevalent in their communities, and we acknowledge that, in the absence of strong political intervention to engender structural changes, our efforts might produce small gains at best. We concur with MacDonald and Terblanche's (2011:73) conclusion: "Within the South African context of poverty, drug abuse, unemployment and HIV/AIDS, the issue of children living on and off the streets should urgently be addressed on different levels and from a multidimensional perspective." Despite the intensity and extent of problems in their home environment, the children and youths, as reflected in this article, did not see street life as a better option. In their comparisons home, shelter and street were equally bad and street life for them was certainly "no millionaire ending!"

\section{REFERENCES}

AFRICAN CHARTER ON THE RIGHTS AND WELFARE OF THE CHILD. OAU. 1990, entered into force in 1990. [Online] Available: http://www1.umn.edu/humanrts/africa/ afchild.htm [Accessed: 18/05/2012].

ANSELL, N. \& VAN BLERK, L. 2004. Children migration as a household/family strategy: Coping with Aids in Lesotho and Malawi. Journal for African Studies, 30(3):673-690.

APTEKAR, L. 1991. Are Columbian street children neglected? The contribution of ethnographic and ethno-historic approaches to the study of children. Anthropology and Education, 22(4):326-329.

CHETTY, V. 1995. A social profile of street children in the Durban municipal area with special reference to their deviant activities. Durban: University of KwaZulu-Natal. (MA thesis)

CONSTITUTION OF THE REPUBLIC OF SOUTH AFRICA, No 108 of 1996. [Online] Available: http://www.info.gov.za/documents/constitution/1996/a108-96.pdf [Accessed: 19/05/2012].

COX, D. \& PAWAR, M. 2006. International social work. Issues, strategies and programs. London: Sage Publications.

DIAMOND, J. 2005. Collapse: how societies choose to fail or survive. London: Penguin Books.

DOMINELLI, L. 2002. Anti oppressive social work theory and practice. London: Palgrave MacMillan.

EPSTEIN, I. 1996. Educating street children: some cross-cultural perspectives. Comparative Education, 32(3):289-302.

EVANS, R. 2002. Poverty, HIV and barriers to education: the street children's experiences in Tanzania. In: Gender, development and poverty: Oxfam focus on gender. Oxford: Oxfam GB.

GILLIGAN, J. 2001. Preventing violence. London: Thames \& Hudson.

HEARN, J. 2007. The problems boys and men create, the problems boys and men experience. In: SHEFER, T., RATELE, K. \& STREBEL, A. (eds) From boys to men. Social 
constructions of masculinity in contemporary society. Cape Town: University of Cape Town Press.

HUMPHRIES, B. 2008. Social work research and social justice. Hampshire: Palgrave, MacMillan.

KARABANOW, J. 2003. Creating a culture of hope: Lessons learnt from street children agencies in Canada and Guatemala. International Social Work, 46(3):369-386.

KRUGER, J.M. \& RICHTER, L.M. 2003. South African street children at risk for AIDS? Children, Youth and Environments, 13(1), Spring. [Online] Available: http://colorado.edu/ journals/cye [Accessed: 22/07/2011].

KUDRATI, M., PLUMMER, M.L. \& YOUSIG, N.D.E.H. 2008. Children of the Sug: a study of the daily lives of street children in Khartoum, Sudan, with intervention recommendations. Child Abuse \& Neglect, 32:439-448.

LALOR, K.J. 1999. Street children: a comparative perspective. Child Abuse \& Neglect, 23(8):759-770.

MACDONALD, J. \& TERBLANCHE, S. 2011. Street children's stories of escaping to, and surviving on, the street - "slumdog" life and "millionaire" ending? Social Work/Maatskaplike Werk, 47(1):73-87.

MOTALA, S. \& SMITH, T. 2003. Exposed to risk: girls and boys living on the streets. Agenda, 56:62-72.

NATIONAL YOUTH POLICY 2009-2014. Republic of South Africa. [Online] Available: http: //www.thepresidency.gov.za/docs/policy/national_youth_policy.pdf. [Accessed: 10/05/2012].

OKOSUN, A. 2008. Transforming global trends: challenging role for social work. Key Note address delivered at the $34^{\text {th }}$ Biannual Global social work congress, $20^{\text {th }}$ July, 2008. Durban.

OSTHUS, I.S. 2011. Sexuality, parenthood, and identity: relationships among female and male youth living on the streets of Durban CBD. Durban: University of KwaZulu-Natal. (MA thesis)

SATHIPARSAD, R. 2008. Developing alternative masculinities as a strategy to address gender based violence. International Social Work, 51(3):348-359.

SEWPAUL, V. 2005. A structural social justice approach to family policy: a critique of the Draft South African Family Policy. Social Work/Maatskaplike Werk, 41(4):310-322.

SEWPAUL, V. \& OSTHUS, I. 2009. Critical Action research: transferring lessons from the streets of New Delhi, India to the streets of Durban, South Africa. In: ZAVIRSEK, D. \& RAMON, S. (eds) Critical edge issues in Social Work and Social Policy. Ljubljana: Faculty of Social Work, University of Ljubljana.

SEWPAUL, V., OSTHUS, I. \& MHONE, C. 2011. Emancipatory pedagogy and community work: the teaching-practice nexus. Social Work/Maatskaplike Werk, 47(4):391-404.

SEXTON, A. 2005. Street children: the situation in East and Southern Africa and the need for a strategic global response. A Presentation to the House Committee on International Relations Subcommittee on Africa, Human Rights and Global Operations. Hearing: Protecting Street children Vigilantes or the rule of Law, $13^{\text {th }}$ September, 2005. 
SOUTH AFRICAN INSTITUTE OF RACE RELATIONS. 2008. South African schools most dangerous in the world - only $23 \%$ of pupils safe. [Online] Available: http://www.sairr.org.za/press-office/archive/south-african-schools-most-dangerous-in-theworld-2013-only-23-of-pupils-safe.html/. [Accessed: 19/05/2011].

SWART-KRUGER, J. \& RICHTER, L.M. 1997. AIDS-related knowledge, attitudes and behaviour among South African street youth. Reflections on power, sexuality and the autonomous self, Soc. Sci. Med., 45(6):957-966.

TRENT, J. 2007. Livelihood strategies of street children in Durban: a participatory, rights-based approach to street-based interventions. Durban, University of KwaZulu-Natal. (MA thesis)

TRENT, J. \& VON KOTZE, A. 2009. A place in society? Strengthening livelihood opportunities for street children- A rights based approach. Social Work/Maatskaplike Werk, 45(2):182-197.

TUDORIC-GHEMO, A. 2005. Life on the street and the mental health of street children: a developmental perspective. Johannesburg: University of Johannesburg. (MA thesis)

UNITED NATIONS CONVENTION ON THE RIGHTS OF A CHILD. 1989. [Online] Available: http://www2.ohchr.org/english/law/crc.htm. [Accessed: 18/05/2012].

UNIVERSAL DECLARATION OF HUMAN RIGHTS. 1948. [Online] Available: http://www. un.org/en/documents/udhr [Accessed: 18/05/2012].

VAVI, Z. 2012. What we must do to create jobs in South Africa. Sunday Times, 12 February 2012.

VEALE, A. \& DONÀ, G. 2003. Street children and political violence: a socio-demographic analysis of street children in Rwanda. Child Abuse and Neglect, 27:253-269.

WARD, C.L., SEAGAR, J. \& TAMASANE, T. 2007. Street children. Report to the Department of social Development, Provincial Government of Gauteng. Pretoria: Human Sciences Research Council. [Online] Available: www.socdev.gpg.gov.za/Street\%20children \%20revised\%20final\%20report.pdf [Accessed: 17/08/2011].

Prof Vishanthie Sewpaul, School of Applied Human Sciences; Ms Ingrid Osthus, Mr Christopher Mhone, Ms Emma Sibilo, Ms Sithembile Mbhele, Social Work students, University of KwaZulu-Natal, Howard College Campus, Durban, South Africa. 